Serials Review, Vol. 25, NO. 4, 1999

Copyright (C) Elsevier Science

http://www.elsevier.com/wps/find/journaldescription.cws_home/620213/description\#description

\title{
What Happened? The Battle For Our Rights In The Digital Age
}

\section{Trisha Davis}

Head, Serials \& Electronic Resources Department, Ohio State University Libraries

Columbus OH 43210-1286

Licensing. We didn't see it coming. No one warned us. And when we first heard about it, we never thought it would have any significant effect on us.

New pricing models. We assumed the standard rules would be applied. No one told us we had to redefine ourselves institutionally. Libraries are sacred to the scholarly communication chain. How could this have happened?

Restrictions on access, authorization of users, and limitations on use. How can they do this to us? Don't they understand what libraries do? We are the guardians of the right to information. We don't ask who, when, how, or why.

As we turn the corner into the new millennium, serialists are caught in the battle for our basic rights to access, retrieve, and use information in the digital age. We were never prepared for this fight and we are struggling to understand how we were caught in the midst of it. Instead of discussions about title changes, claims, vendor evaluation, and union listing, we're busy trying to understand the idiosyncracies of the Internet, basic legal foundations of contract law, and how to manage our virtual collections. We came to the battlefield unarmed and unprepared.

In the mid-1970s we applauded the new copyright laws, although we were not exactly clear on how they applied to us. We were libraries, after all, and our rights were surely guaranteed. Then we learned that if we posted a warning notice on all the photocopiers and made sure to keep accurate records of our reserves activity, we were OK. Serialists remained aloof from these issues and continued to focus on acquisition problems, cataloging, and bibliographic control. After all, serials were a booming industry and the scholarly communication chain was expanding at an exponential rate.

Some of us heard stories about how our colleagues in the audiovisual world didn't have it quite so easy. They now had to sign multiple copy rental agreements and confirm that films were shown in approved classrooms and to students only. Those requirements seemed reasonable and typically bureaucratic. After all, the film industry had been booming for a few decades. We were happy that they were beginning to support education - and libraries had no interest in trying to compete with them!

Activities in the copyright arena during the first half of the 1980s seemed reassuring. Fair use rights were defined and assured, and traditional library usage was protected. Interlibrary loan activity was acknowledged, and workable means were created to assure that any necessary royalties were paid. Serialists were encouraged about the new standards for serials cataloging and the ability to share the original cataloging burden via OCLC. The automated functions their integrated library system vendors were designing were simplifying library work and expanding 
library services. Automation of library catalogs and serials holdings captured our interest and our resources.

Serial agents were our friends and allies in the new age of automation. As they built huge databases of serial titles and subscription activities, serialists benefited enormously. The agents provided us with lists of titles, title changes, fund codes, orders, cancellations, cessations, payments, and credits. Management tasks were both simplified and enhanced by all the new data available. We had much better control of our collections as we made selection and retention decisions. The sheer volume of titles being published was expanding so rapidly that we turned our focus to resource sharing and collection development activities.

Only a few librarians were involved with acquiring and licensing software for use. During the mid-1980s only those in automation departments dealt with the acquisition of computer systems and software. Even as computer systems entered the library, they were primarily dumb terminals. We were the only end users. As the first computer labs were funded, librarians were more concerned with site preparation, security, machine set-up, and training users on the basic functions. Like everyone else, serialists were fascinated with word processing but seldom became involved in other aspects of personal computing. We failed to notice, or pay attention to, or understand the shrink-wrapped license notices that accompanied the diskettes. It didn't seem to be our problem.

The early 1990s found us enamored of the advances in our local systems, the prospects of e-mail via the Internet, CD-ROM databases, and the fascinating developments on the World Wide Web (WWW). Serial agents were allowing direct access to their computer systems; systems vendors were designing acquisitions and serials control modules that were integrated into the online catalog. Serialists spent most of the first half of this decade converting from manual order, check in, and binding files to integrated online functions.

Serialists also began to use the Internet in various ways: communication with serial agents, online discussion groups, and e-mail with our peers around the country. The WWW was still a toy, and most libraries only had the equipment to run CD-ROMs at standalone workstations. A few databases, even individual titles, had started to appear on tape or diskette, and we had to figure out what to do with them in terms of receipt and processing. Although licenses were present, they were deemed to be issues for the systems staff. When CD-ROM versions arrived, we followed the same procedures and worried mostly about cataloging them.

The proliferation of campus-wide information systems (CWIS) was the first warning to serialists that life as we knew it would change dramatically. The concept of actually distributing these files and databases from our own campus network or library system was a dramatic shift. The very nature of these titles (they were published serially or updated on a regular basis) pulled the serialist into the fray. Suddenly the language of the shrink-wrapped license that accompanied the diskettes and CD-ROMs was not quite acceptable. Most licenses were still focused on a single user at a single workstation, while we needed rights for a local area network that involved multiple computers in multiple buildings.

As serialists and serial agents began to work with electronic publishers, it quickly became clear that these publishers were not library-oriented. Their products and their licenses were developed with the end user in mind. Their marketing, sales, and service staffs were ignorant of libraries as customers and how libraries would acquire and use their products. At this time, licenses were simple but prohibited many of the primary access and use needs of the library. The cold war had begun. 
By the mid-1990s, both electronic publishers and serialists were beginning to respond to each other in tentative ways. A few of the major electronic publishers, such as SilverPlatter and HW Wilson, revised their license agreements to recognize LANs and to allow simultaneous users (at an additional cost, of course). As other electronic publishers followed suit, however, license agreements became more complex and more restrictive. Passive, shrink-wrapped licenses led to more lengthy legal documents that required a formal signature that contractually obligated the entire institution to the terms of the license. Serialists began to realize that the process had moved out of their control.

To add fuel to the fire, licenses began to restrict access, define authorized users and sites, and forbid some traditional library activities, such as interlibrary loan and archiving. The electronic publishers stated that they were simply protecting their rights in the digital age; the serialists felt that fair use rights should be protected regardless of the format. Open forums, plenary sessions, and discussion groups at professional meetings quickly ensued. Their goals were to get a better understanding of the issues and to begin a dialogue between the warring parties. Workshops were developed to educate not only serialists and electronic publishers in particular but also librarians and publishers in general.

And here we are: some battles won, some lost, and the war for our rights continues. Yes, both serialists and electronic publishers have much more information than ever, but answers evade us. We have principles from national and international library groups for both sides to follow. We have generic sets of license terms from various interested parties. Even the serial agents are developing strategies to bring both sides together. The Digital Millennium Copyright Act of 1998 provides some hope as a peace treaty, but completion of the content and confirmation by Congress is far from a reality.

At the turn of the twentieth century, libraries were on the rise as the keystone to higher education and as a basic public institution. At the end of this century, those very rights are threatened with extinction by the information industry through licensed rights, unreasonable costs, and the power of contract law. What happened? How did libraries get pulled into this war? When will it end? What will the outcome be? No clear answers are available at the moment, but rest assured that serialists are fighting hard for our rights. 